\title{
Novel insights into ion channels in cancer stem cells (Review)
}

\author{
QIJIAO CHENG $^{1 *}$, ANHAI CHEN ${ }^{1 *}$, QIAN DU ${ }^{1}$, QIUSHI LIAO ${ }^{1}$, ZHANGLI SHUAI $^{1}$, CHANGMEI CHEN $^{1}$, \\ XINRONG YANG ${ }^{1}$, YAXIA HU ${ }^{1}$, JU ZHAO ${ }^{1}$, SONGPO LIU ${ }^{1}$, GUO RONG WEN ${ }^{1}$, \\ JIAXIN AN $^{1}$, HAI JING ${ }^{1}$, BIGUANG TUO ${ }^{1}$, RUI XIE ${ }^{1}$ and JINGYU XU ${ }^{1,2}$ \\ ${ }^{1}$ Department of Gastroenterology, Affiliated Hospital of Zunyi Medical College, Zunyi, Guizhou 563003, P.R. China;
${ }^{2}$ Department of Gastroenterology, Hepatology and Endocrinology, Hannover Medical School, 30625 Hannover, Germany
}

Received February 15, 2018; Accepted June 28, 2018

DOI: 10.3892/ijo.2018.4500

\begin{abstract}
Cancer stem cells (CSCs) are immortal cells in tumor tissues that have been proposed as the driving force of tumorigenesis and tumor invasion. Previously, ion channels were revealed to contribute to cancer cell proliferation, migration and apoptosis. Recent studies have demonstrated that ion channels are present in various CSCs; however, the functions of ion channels and their mechanisms in CSCs remain unknown. The present review aimed to focus on the roles of ion channels in the regulation of CSC behavior and the CSC-like properties of cancer cells. Evaluation of the relationship between ion channels and CSCs is critically important for understanding malignancy.
\end{abstract}

\section{Contents}

1. Introduction

2. Ion channels and CSCs

3. Ion channel blockers as a novel target for cancer

4. Conclusion

\section{Introduction}

Cancer stem cells (CSCs). Cancer is a leading cause of mortality worldwide. In China, $\sim 4$ million new cases of cancer were diagnosed in 2015 , and $50 \%$ of all mortalities were associated with cancer (1). Surgery, chemotherapy and/or radiotherapy are used to treat the majority of cancers and to improve survival of patients. These clinical measures

Correspondence to: Dr Jingyu Xu or Dr Rui Xie, Department of Gastroenterology, Affiliated Hospital to Zunyi Medical College, 201 Dalian Road, Zunyi, Guizhou 563003, P.R. China

E-mail: xujingyu_gzzy@126.com

E-mail: xr19841029@aliyun.com

*Contributed equally

Key words: ion channels, cancer stem cells, tumorigenesis, invasion have proven efficaciousinseveral cases; however, few patients survive $>5$ years due to the high recurrence and metastasis of tumor cells; CSCs are considered the root of tumor recurrence and metastasis $(2,3)$.

CSCs have been identified and characterized in various tumor types; in particular, CSCs exhibit self-renewal, multilineage differentiation and tumor initiation capacities, and proliferative potential (4). Targeting of CSCs or inhibition of important properties including self-renewal, differentiation and apoptosis resistance are novel therapeutic strategies (Fig. 1). Several lines of evidence have indicated that CSCs serve a key role in tumorigenesis, recurrence and metastasis (5-7). When tumors occur, CSCs are considered to be the origin of abnormal differentiation; uncontrolled self-renewal of CSCs induces malignant transformation and rapid proliferation of cells. In advanced tumor stages, once activated, CSCs can promote tumor development and metastasis by regulating tumor angiogenesis (8). Notably, the current antitumor drugs mainly target rapidly proliferating mitotic cells; however, CSCs are usually dormant or quiescent, and can therefore exhibit immune escape and resist the suppressive effects of chemotherapy drugs, thereby becoming the root of tumor recurrence (3). Therefore, CSCs are considered to be the key to tumor recurrence and metastasis of seed cells and malignant tumors. Previous studies have suggested that there are three major sources of CSCs, as follows: i) Normal stem or progenitor cells are malignantly transformed into CSCs due to gene mutations; ii) viral infection or formation of CSCs through intercellular fusion $(9,10)$; iii) mature end-stage tumor cells regain CSC-like properties induced by ionizing radiation, hypoxia or the tumor microenvironment $(11,12)$. In addition, both inflammatory factors [interleukin (IL) 6, and transforming growth factor (TGF)- $\beta$ ], and cytokines [endothelial growth factor (EGF) and vascular (EGF)] regulate CSC growth and maintenance (Fig. 2).

Ion channels and tumors. Previous studies have reported that ion channels serve an important role in cancer development $(13,14)$. Numerous ion channels have been confirmed to be highly expressed in various tumor types and are closely associated with tumor cell biological behaviors (15-17). Ion channels are specific hydrophilic microporous proteins that exhibit selective permeability for various ions; they are usually named according to the ions with the highest permeability, 
including potassium $\left(\mathrm{K}^{+}\right)$channels, calcium $\left(\mathrm{Ca}^{2+}\right)$ channels and chloride $\left(\mathrm{Cl}^{-}\right)$channels. These ion channels are distributed in almost every cell membrane of the body and have an important role in the physiology and pathology of excitable cells with regards to the following aspects: i) Determination of cell excitability, conductivity, contractility and rhythmicity; in nerve, muscle and other excitable cells, $\mathrm{Na}^{+}$and $\mathrm{Ca}^{2+}$ channels mainly regulate depolarization, whereas $\mathrm{K}^{+}$channels mainly regulate repolarization and maintain the resting potential $(18,19)$; ii) regulation of vasomotor smoothing and contraction activities (20); iii) participation in synaptic transmission (21); iv) maintenance of normal cell volume $(22,23)$; v) regulation of intracellular cAMP, cGMP, $\mathrm{Ca}^{2+}$ and other second messenger concentrations, in order to trigger muscle contraction, glandular secretion, protein kinase activation and gene expression regulation $(24,25)$. The normal structure and function of ion channels are the basis for cells to carry out their normal activities. Mutations in specific ion channel sites lead to abnormalities in their activation and inactivation, causing cell dysfunction and the formation of various diseases, including epilepsy and arrhythmia, and skeletal muscle dysfunction $(26,27)$. Disorders associated with aberrant ion channel functions are commonly known as 'ion channel diseases' $(28,29)$.

At present, few reports have focused on the association between ion channels and CSCs. Our recent work indicated that solute carrier family 8 member A1 and transient receptor potential cation channel subfamily $\mathrm{C}$ member 6 are expressed in cluster of differentiation (CD) $133^{+}$stem cells in Huh7 hepatic cancer cells, thus indicating that ion channels may be involved in the occurrence and development of cancer (30). Furthermore, ion channel inhibitors can reduce drug resistance of tumor cells via regulation of CSC function $(31,32)$. The present review aimed to summarize the roles of ion channels, and describe their expression and function in CSCs. Further evaluation of the association between ion channels and CSCs is critically important to understand malignancy.

\section{Ion channels and CSCs}

Association between $\mathrm{Ca}^{2+}$ channels and CSCs. Cytosolic $\mathrm{Ca}^{2+}\left(\left[\mathrm{Ca}^{2+}\right]_{\text {cyt }}\right)$ has an important role in intracellular signal transduction, and participates in a series of physiological and pathological processes in the body (33). Under normal circumstances, intracellular $\mathrm{Ca}^{2+}$ concentrations are usually maintained within an appropriate concentration range and are regulated by a series of precise regulatory systems (34). However, this balance is disrupted under pathological conditions. It has previously been reported that in the tumor cells, intracellular $\mathrm{Ca}^{2+}$ levels may be disrupted, thus affecting the intracellular $\mathrm{Ca}^{2+}$ balance, which leads to excessive activation of associated signals that encode alterations in intracellular $\mathrm{Ca}^{2+}$ (including source, amplitude and frequency) $(35,36)$. This induces a subsequent upregulation in oncogene expression, which promotes the development of tumors (32). The intracellular $\mathrm{Ca}^{2+}$ balance is primarily regulated by $\mathrm{Ca}^{2+}$ channels in the membrane and organelles; therefore, it is important to study the role of $\mathrm{Ca}^{2+}$ channels and their subtypes in tumorigenesis, development, invasion and metastasis.
There are several known $\mathrm{Ca}^{2+}$ channels: Voltage-gated $\mathrm{Ca}^{2+}$ channels (VGCCs), ligand-gated $\mathrm{Ca}^{2+}$ channels, store-operated $\mathrm{Ca}^{2+}$ channels and transient receptor potential channels, and $\mathrm{Na}^{+} / \mathrm{Ca}^{2+}$ channels. VGCCs belong to the $\mathrm{CaV}$ family and are involved in $\mathrm{Ca}^{2+}$ influx; VGCCs are divided into L-type $\mathrm{Ca}^{2+}$ channels, T-type $\mathrm{Ca}^{2+}$ channels, P-type $\mathrm{Ca}^{2+}$ channels, matrix interaction molecule-1 (STIM1) and the $\mathrm{Ca}^{2+}$ release-activated $\mathrm{Ca}^{2+}$ channel protein-1 (Orai1). STIM1 and inositol trisphosphate receptor combine with membrane uncoupling and Orail to induce $\mathrm{Ca}^{2+}$ influx $(37,38)$.

Lee et al revealed that Orai, a key calcium channel for store-operated $\mathrm{Ca}^{2+}$ entry, is highly expressed in CSC-enriched populations of human oral/oropharyngeal squamous cell carcinoma (OSCC). In addition, the activation of Orail promotes cancer self-renewal via nuclear factor of activated T-cells signaling. Overexpression of Orail promotes self-renewal in OSCC and increases the expression of enhancer of zeste homolog 2, Hes1, zinc finger E-box-binding homeobox 2 and interleukin 4. Conversely, inhibition of Orail suppresses cancer self-renewal in OSCC (39). Zhao et al detected overexpression of the $\mathrm{Ca}^{2+}$ channel $\alpha 2 \delta 1+$ subunit in hepatocellular carcinoma (HCC) CSCs. These HCC CSCs exhibit stem cell-like properties, such as increased self-renewal, increased invasiveness and expression of stem cell-associated genes (octamer-binding transcription factor 4, SRY-box 2, Nanog homeobox and BMI1 proto-oncogene, polycomb ring finger) (40).

Liu et al demonstrated that silencing the expression of transient receptor potential cation channel subfamily $\mathrm{M}$ member 7 (TRPM7) in glioma stem cells was able to induce the Notch and signal transducer and activator of transcription 3 pathways, which were downregulated in glioma stem cells. TRPM7 is a ubiquitous ion channel permeable to $\mathrm{Ca}^{2+}$ and $\mathrm{Mg}^{2+}$. Activation of TRPM7 upregulates the CSC markers aldehyde dehydrogenase 1 (ALDH1) and CD133; TRPM7 activates ALDH1 activity to promote proliferation, migration and invasion of glioma cells (41). In addition, Morelli et al evaluated the abnormal expression of transient receptor potential cation channel subfamily V member 2 (TRPV2) in glioblastoma (GBM) CSCs. TRPV2 was revealed to promote in vitro and in vivo GBM CSC differentiation and inhibit their proliferation (42). $\mathrm{Ca}^{2+}$-activated $\mathrm{K}^{+}$-channels $\left(\mathrm{BK}_{\mathrm{Ca}}\right)$ are associated with a poor cancer prognosis, and are highly expressed in $\mathrm{CD}_{133^{+}}$SH-SY5Y neuroblastoma cells and human GBM CSCs (43). The $\mathrm{BK}_{\mathrm{Ca}}$ channels may be used as a novel marker for GBM, in order to improve the personalization and accuracy of GBM therapy (44). Zhang et al reported that activation of $\mathrm{BK}_{\mathrm{Ca}}$ in rats could promote the transformation of human bone marrow-derived mesenchymal stem cells (MCSs) from $\mathrm{G}_{1}$ to $\mathrm{S}$ phase, and increase the mRNA and protein expression levels of cyclin D1 (45). Conversely, inhibition of $\mathrm{BK}_{\mathrm{Ca}}$ activity was able to downregulate the expression of mRNA and protein expression levels of cyclin D1, thus inhibiting the proliferation of bone marrow MSCs. Inhibition of $\mathrm{BK}_{\mathrm{Ca}}$ with paxilline or silencing $\mathrm{BK}_{\mathrm{Ca}}$ reduces cell proliferation in human bone marrow-derived MSCs (45). The $\mathrm{Ca}^{2+}$ channels mediating calcium signaling play an important role in proliferation, cell death, migration and invasion during the course of tumorigenesis. Therefore, these findings highlight the elusive role of $\mathrm{Ca}^{2+}$ channels and their functions in CSC biology (46). 


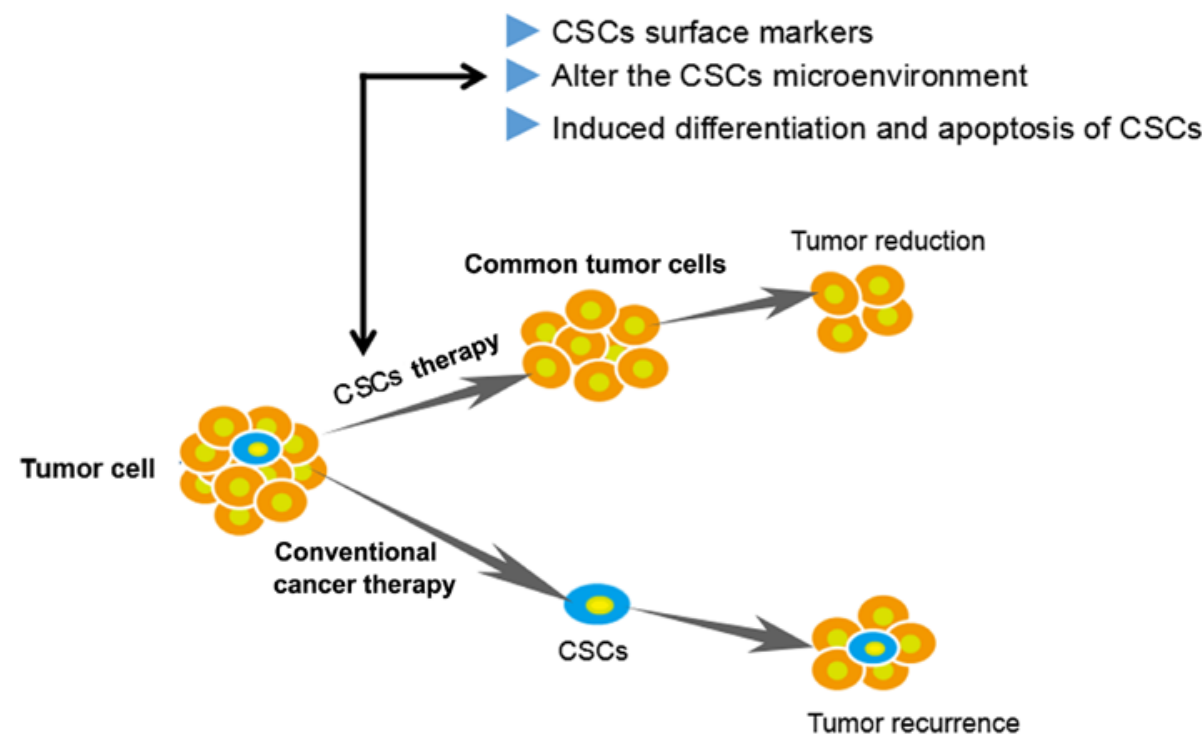

Figure 1. Evolution of CSCs and conventional cancer therapies. Malignant tumors are commonly seen in many human organs, and several traditional methods are used to treat these cancers, including surgery, chemotherapy and radiation. The CSC is an ideal target cell, which possesses self-renewal and multi-lineage differentiation capabilities. CSCs can escape the suppressive effects of normal drugs, and promote tumor recurrence and metastasis. CSC-targeted treatment aims to target specific surface markers of CSCs, affect the CSC microenvironment and induce differentiation and apoptosis of CSCs. These methods may reduce tumor recurrence, which is the root cause of invasion, consequently shrinking the tumor. CSCs, cancer stem cells.

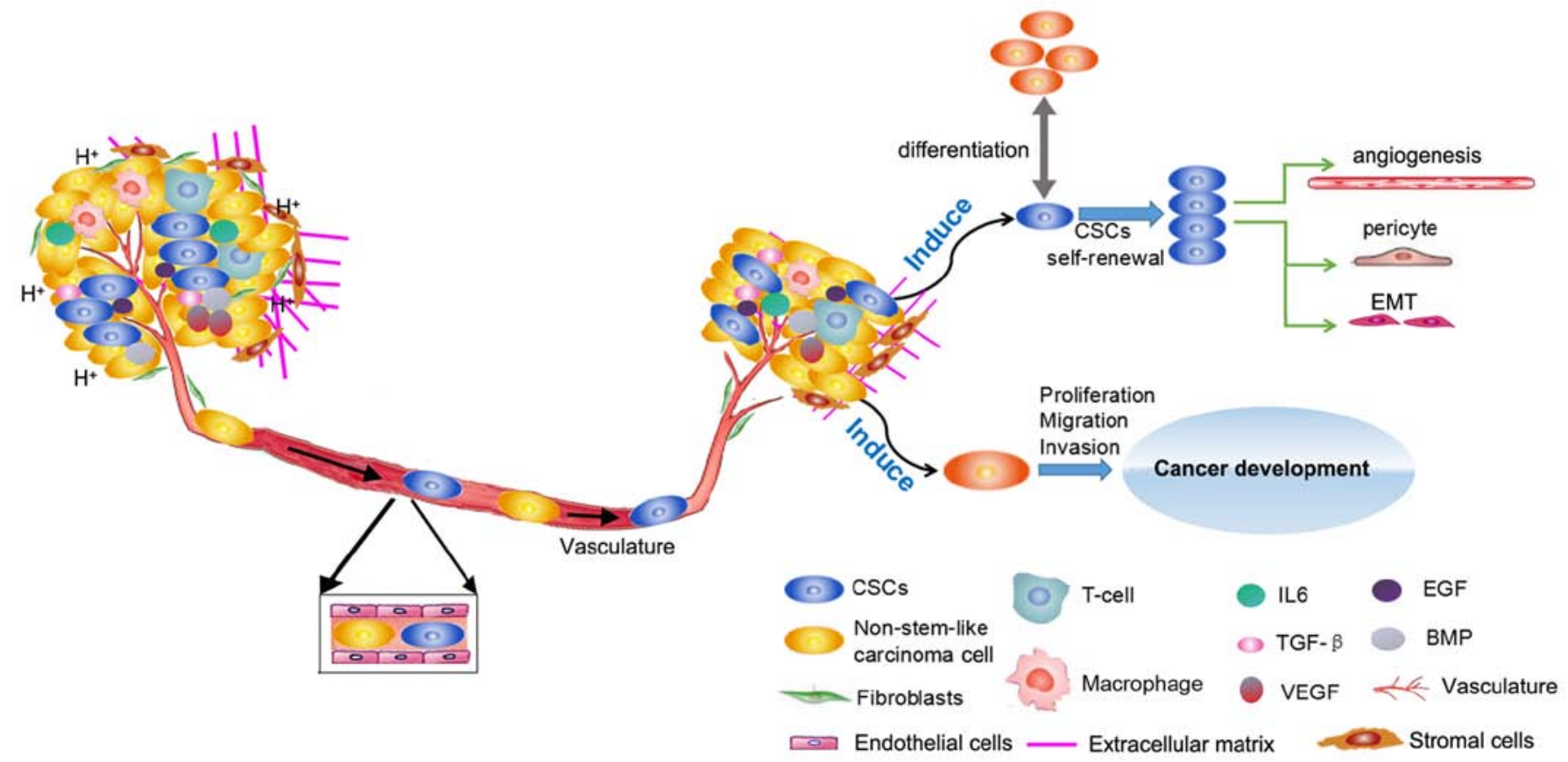

Figure 2. Microenvironment contributes to tumor progression and metastasis. The tumor microenvironment includes tumor cells, CSCs, stromal cells, fibroblasts, tumor vasculature and extracellular matrix, etc. These cells can secrete IL6, BMP, EGF, VEGF, TGF- $\beta$ and other factors [e.g. neuroendocrine (NE) cells, adipose cells, and the blood networks]. These factors induce the self-renewal and pluripotent differentiation capabilities of CSCs. Furthermore, these factors promote tumor development via stimulating angiogenesis and EMT. BMP, bone morphogenetic protein; CSCs, cancer stem cells; EGF, epidermal growth factor; EMT, epithelial-mesenchymal transition; IL6, interleukin 6; TGF- $\beta$, transforming growth factor- $\beta$; VEGF, vascular endothelial growth factor.

$K^{+}$channels. $\mathrm{K}^{+}$channels are hydrophilic proteins that form microchannels in the cell membrane with specificity for $\mathrm{K}^{+}$. The residue side chains selectively interact with the ions and provide specific permeability barrier function. $\mathrm{K}^{+}$channels are the most widely distributed and most common class of channels, which participate in the resting potential of action potential repolarization and serve a crucial role in regulating various biological functions in organisms (47-49). These chan- nels include voltage-gated $\mathrm{K}^{+}$channels $(\mathrm{Kv})$, inward rectifier $\mathrm{K}^{+}$channel, and $\mathrm{BK}_{\mathrm{Ca}}$, among others. $\mathrm{Kv}$ also includes ethera-go-go-related gene (ERG), Kv2, Kv7 (KCNQ) $\mathrm{K}^{+}$channel family, ether-à-go-go family of voltage-gated $\mathrm{K}^{+}$channels and other common subfamilies (50).

The role of $\mathrm{K}^{+}$channels in CSCs. Kv1.3 (together with $\mathrm{KCa} 3.1$ ) has been implicated in the control of cell proliferation in rat 


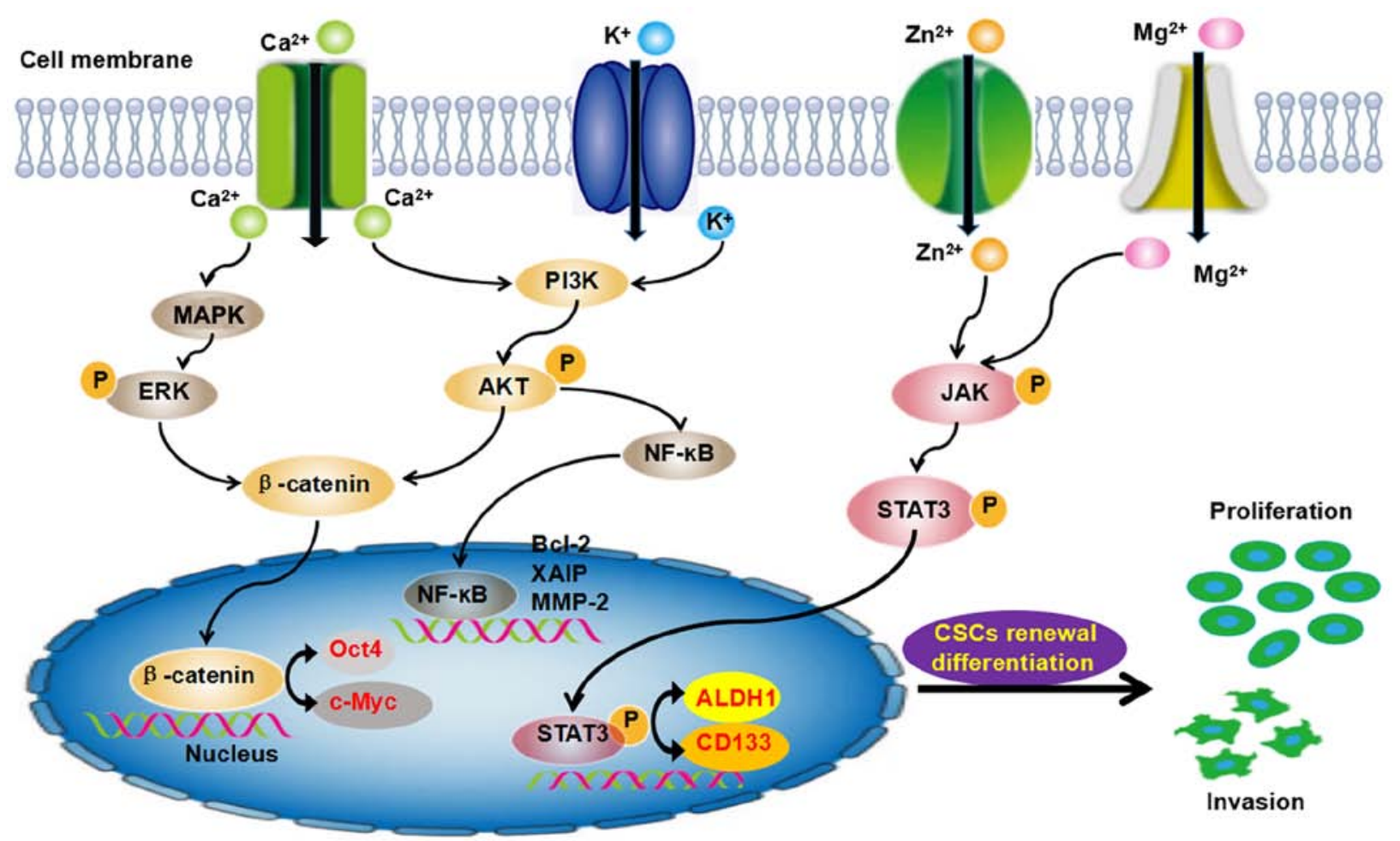

Figure 3. Overview of select signaling pathways associated with CSC maintenance, survival, proliferation and invasion. Ion channel expression in the CSCs membrane, including $\mathrm{Ca}^{2+}, \mathrm{Mg}^{2+}, \mathrm{K}^{+}$and $\mathrm{Zn}^{2+}$ channels. These channels are activated and transmit signals through other factors, such as MAPK/ERK, PI3K/ Akt, JNK, STAT3, Wnt and NF- $\mathrm{kB}$. These novel regulatory mechanisms may promote self-renewal and differentiation, and thereby provide avenues for therapeutic intervention. MAPK, mitogen-activated protein kinase; ERK, extracellular signal-regulated kinase; PI3K, phosphoinositide 3-kinase; Akt, protein kinase B; NF-кB, nuclear factor- $\mathrm{B}$; ALDH1, aldehyde dehydrogenase 1; Bcl-2, B-cell lymphoma 2; CD133, cluster of differentiation 133; CSCs, cancer stem cells; JAK, Janus kinase; MMP-2, matrix metalloproteinase 2; Oct4, octamer-binding transcription factor 4; STAT3, signal transducer and activator of transcription 3; XIAP, X-linked inhibitor of apoptosis protein.

MSCs; silencing KCa3.1 inhibits the proliferation of rat bone marrow MSCs by inducing cell cycle arrest at the $\mathrm{G}_{0} / \mathrm{G}_{1}$ phase (51). The voltage-sensitive human ERG (hERG, Kv11.1) $\mathrm{K}^{+}$channel acts as a regulator of proliferation and survival in cancer cells $(52,53)$. The expression of Kv11.1 has been reported in several cancer types, as well as cancer cell lines of different lineages, such as epithelial, leukemic, connective or neuronal cells. Recently, Li et al reported that hERG (Kv11.1) is highly expressed in $\mathrm{CD} 34^{+} / \mathrm{CD} 38 \%$ CD123 leukemia stem cells (LSCs), interferes with the cell cycle and promotes tumor cell proliferation. Furthermore, the hERG-specific blocker E-4031 inhibits LSC proliferation, by inhibiting $\mathrm{G}_{1} / \mathrm{S}$ phase transition (54). Another hERG inhibitor, clofilium, destroys the osmotic pressure balance of LSCs intra- and extracellularly via $\mathrm{K}^{+}$-induced cell swelling and rupture. These results suggest that $\mathrm{hERG}$ channels may be involved in regulation of the LSC cycle, and that LSCs maintain a constant volume by adjusting osmotic pressure inside and outside of the cell (55).

$\mathrm{K}^{+}$channel tetramerization domain containing 12 (KCTD12) is a biomarker for clinical prognosis in patients with gastrointestinal cancer following chemotherapy (56). Using a cancer cell-forming test that selects CSCs from the colorectal cancer (CRC) HT29 cell line, Li et al revealed that the expression of KCTD12 is downregulated in the CSC-like cells of CRC. Inhibition of endogenous KCTD12 and overexpression of KCTD12 markedly enhance and suppress CRC cell selfrenewal ability, respectively. Furthermore, silencing KCTD12 enhances drug resistance to 5-fluoruracil in HT29 cells (57).
Together, the $\mathrm{K}^{+}$channel activity is an important event that controls several cellular functions including cell proliferation and cell cycle in CSCs. The results provide evidence for the role of $\mathrm{K}^{+}$channel and it may be a novel, potential pharmacological target for tumor therapy in the future.

$\mathrm{Cl}^{-}$channels. $\mathrm{Cl}^{-}$channels are the most abundant and physiologically important anion channels in organisms. Their classification is more complex, including voltage-gated (CLC), $\mathrm{Ca}^{2+}$-dependent, swelling-activated $\mathrm{Cl}^{-}$channel, $\gamma$ aminobutyric acid-activated (GABA) $\mathrm{Cl}^{-}$channels (58). Various $\mathrm{Cl}^{-}$channels have been reported to exhibit different functions in tumor cells (59). Soroceanu et al detected CLC expression in human malignant glioma cells, which are sensitive to the $\mathrm{Cl}^{-}$ toxin chlorotoxin; however, CLC is not expressed in normal tissue. The CLC-specific inhibitor chlorotoxin can inhibit tumor cell invasion of the surrounding tissues, thus suggesting that $\mathrm{Cl}^{-}$channels have an important role in the tumor cell cycle (60).

The role of $\mathrm{Cl}^{-}$channels in CSCs. In recent decades, growing scientific evidence has supported the potential involvement of ion channels in tumorigenesis and carcinogenesis. Setti et al indicated that $\mathrm{Cl}^{-}$intracellular channel protein 1 (CLIC1) is overexpressed in GBM CSCs, where it serves an important role in GBM CSCs self-renewal and proliferation; CLIC1 is primarily detected in the nuclear membrane and in the plasma membrane. In addition, Setti et al demonstrated that 
overexpression of CLIC1 in GBM CSCs is negatively correlated with patient survival. Conversely, silencing CLIC1 inhibits the proliferation, cloning and tumorigenicity of GBM (61). These results may indicate a novel therapeutic approach targeted to GBM. CLIC1 may be considered an attractive target in the CSC population that could finally cure GBM. Compared with CLIC1, CLIC4 is expressed in metastatic CSCs and is associated with the prognostic risks of colorectal cancer (62). In conclusion, $\mathrm{Cl}^{-}$channels may serve an important role in tumor cell migration and tumor metastasis; therefore, $\mathrm{Cl}^{-}$channels may be potential drug targets for the treatment of tumors.

\section{Ion channel blockers as a novel target for cancer}

In recent years, ion channel drugs have been widely used in clinical practice. It has been reported that various ion channel blockers can affect the proliferation, differentiation, apoptosis and metastasis of tumor cells in numerous types of cancer (58). Inhibiting the $\mathrm{K}^{+}$efflux can promote apoptosis, and a $\mathrm{K}^{+}$channel inhibitor may reverse multidrug resistance (MDR) in tumor cells (63). Zhao et al reported that the $\mathrm{Ca}^{2+}$ channel blocker verapamil targets MDR-associated proteins, inhibits pancreatic CSC (gemcitabine-resistant) proliferation and promotes apoptosis of pancreatic cancer cells (64). The specific inhibitor of the Kv1.3 channel aflatoxin (MgTX) and the non-specific inhibitor 4-AP can suppress prostate cancer cell metastasis and lung cancer cell proliferation. Additionally, MgTX can promote prostate cancer cell apoptosis by regulating the transition to the $\mathrm{G}_{1}-\mathrm{S}$ phase (65). Treatment with the KCa3.1 blocker TRAM-34 and temozolomide (TMZ) is able to significantly reduce DNA synthesis, as well as GBM and CSC survival, compared with TMZ alone. Notably, TMZ/TRAM-34 combination therapy can reduce infiltration of glioma cells $(66,67)$. CSCs isolated from GBM are highly resistant to bis-chloroethylnitrosourea (BCNU) in vitro, whereas the combination of $\mathrm{BCNU}$ and a $\mathrm{Cl}^{-}$channel inhibitor 4,4'-diisothiocyanostilbene-2,2'-disulfonic acid inhibits the proliferation and promotes apoptosis of BCNU-resistant CSCs (63). CLIC1 is involved in the resistance of BCNUresistant CSCs and BCNU/DIDS combined-therapy can provide valuable insight for promoting apoptosis or sensitizing glioblastomas to BCNU chemotherapy. These results suggest that CLIC1 may be a drug efflux channel that participates in the resistance of GBM CSCs to BCNU (68). In addition, the use of a blocker [5-nitro-1-(3-phenylpropyl amino) benzoic acid] or small interfering RNA silencing of $\mathrm{CLCN} 3 \mathrm{Cl}^{-}$volume sensitive channel expression, as well as mRNA and protein downregulation of cyclin D and E, inhibits MSCs proliferation in vitro. Furthermore, Gritti et al revealed that metformin can inhibit CLIC1 channel function and reduce the survival of human GBM CSCs, and short hairpin RNA against CLIC1 significantly increases the inhibitory effects of metformin on human GBM CSC activity (69). In addition to $\mathrm{K}^{+}$and $\mathrm{Cl}^{-}$ channel inhibitors, $\mathrm{Ca}^{2+}$ channel inhibitors may reverse cancer cell MDR (70,71).

\section{Conclusion}

The novel concept of CSCs was introduced in the late 1990s, and numerous research efforts have aimed to elucidate its role over the past decades $(72,73)$. This concept may influence all approaches of cancer biology, since CSCs have an important role in tumorigenesis, drug resistance $(74,75)$, invasion, metastasis and recurrence. The function of CSCs is predominantly regulated by microenvironmental factors that provide an adaptive landscape for relapsed tumor cells (76-78). Therefore, identifying novel methods for preventing CSC drug resistance could improve the longterm survival of patients. The main factors controlling CSCs include epithelial-mesenchymal transition and the niche environment $(79,80)$. In recent years, the potential regulatory role of ion channels in the tumor microenvironment has been widely recognized, due to the abnormal expression of ion channels in CSCs, and various mechanisms regulating tumorigenesis, malignant transformation and metastasis (81-84). Moreover, those ion channels further induced the aberrant activation of signaling pathways and play important roles in the evolution of cancer development. The PI3K/Akt, JNK, STAT3, Wnt and NF-KB pathways are involved in the self-renewal of CSCs (Fig. 3). These findings have provided novel information, which may aid the eradication of CSCs, improve the efficacy of antitumor drugs and result in a potential cure. Some ion channel agonists or antagonists demonstrate antitumor activity in specific CSCs, which provides a theoretical basis for clinical implementation (83). Additional in-depth research regarding the relationship between ion channels and MDR may lay the foundation for the development of novel agents through drug design and development. Novel perspectives will be gained from the characterization of various ion channel structures and may promote the development of anti-CSC drug targets. It has been hypothesized that through further exploration of the relationship between ion channels and CSCs, ion channels may be revealed to participate in the regulation of CSC pathways, and their inhibitors may provide more information regarding clinical targets in CSC-targeted therapy.

\section{Acknowledgements}

The authors would like to thank Professor Biguang Tuo (Department of Gastroenterology, Affiliated Hospital of Zunyi Medical College) for highly professional services.

\section{Funding}

The present study was supported by research grants from the National Natural Science Foundation of China (grant no. 816660412 to RX, grant no. 81160265 to JYX, grant no. 81360311 to $\mathrm{HJ})$.

\section{Availability of data and materials}

Not applicable.

\section{Authors' contributions}

$\mathrm{QC}$, and $\mathrm{AC}$ wrote the manuscript; QD, QL, ZS, CC, XY, YH, JZ, SL, GW, JA and HJ collect the literature; BT and RX. primarily revised and finalized manuscript. JX revised the manuscript for clarity and style. 


\section{Ethics approval and consent to participate}

Not applicable.

\section{Patient consent for publication}

Not applicable.

\section{Competing interests}

The authors declare that they have no competing interests.

\section{References}

1. Chen W, Zheng R, Baade PD, Zhang S, Zeng H, Bray F, Jemal A Yu XQ and He J: Cancer statistics in China, 2015. CA Cancer J Clin 66: 115-132, 2016

2. Hardingham JE, Grover P, Winter M, Hewett PJ, Price TJ and Thierry B: Detection and clinical significance of circulating tumor cells in colorectal cancer - 20 years of progress. Mol Med 21 (Suppl 1): S25-S31, 2015.

3. Shiozawa Y, Nie B, Pienta KJ, Morgan TM and Taichman RS: Cancer stem cells and their role in metastasis. Pharmacol Ther 138: 285-293, 2013.

4. Dalerba P, Cho RW and Clarke MF: Cancer stem cells: Models and concepts. Annu Rev Med 58: 267-284, 2007.

5. Fan ST, Yang ZF, Ho DW, Ng MN, Yu WC and Wong J: Prediction of posthepatectomy recurrence of hepatocellular carcinoma by circulating cancer stem cells: A prospective study. Ann Surg 254: 569-576, 2011.

6. Chinn SB, Darr OA, Peters RD and Prince ME: The role of head and neck squamous cell carcinoma cancer stem cells in tumorigenesis, metastasis, and treatment failure. Front Endocrinol (Lausanne) 3: 90, 2012.

7. Nandy SB and Lakshmanaswamy R: Cancer stem cells and metastasis. Prog Mol Biol Transl Sci 151: 137-176, 2017.

8. Ribatti D: Cancer stem cells and tumor angiogenesis. Cancer Lett 321: 13-17, 2012.

9. Marusyk A, Almendro V and Polyak K: Intra-tumour heterogeneity: A looking glass for cancer? Nat Rev Cancer 12: 323-334, 2012.

10. Ansieau S: EMT in breast cancer stem cell generation. Cancer Lett 338: 63-68, 2013

11. Wei J, Wu A, Kong LY, Wang Y, Fuller G, Fokt I, Melillo G, Priebe W and Heimberger AB: Hypoxia potentiates gliomamediated immunosuppression. PLoS One 6: e16195, 2011.

12. Salnikov AV, Liu L, Platen M, Gladkich J, Salnikova O, Ryschich E, Mattern J, Moldenhauer G, Werner J, Schemmer P, et al: Hypoxia induces EMT in low and highly aggressive pancreatic tumor cells but only cells with cancer stem cell characteristics acquire pronounced migratory potential. PLoS One 7: e46391, 2012.

13. Takanami I, Inoue Y and Gika M: G-protein inwardly rectifying potassium channel 1 (GIRK 1) gene expression correlates with tumor progression in non-small cell lung cancer. BMC Cancer 4: 79-85, 2004

14. Stringer BK, Cooper AG and Shepard SB: Overexpression of the G-protein inwardly rectifying potassium channel 1 (GIRK1) in primary breast carcinomas correlates with axillary lymph node metastasis. Cancer Res 61: 582-588, 2001.

15. Zhang Y, Wang H, Qian Z, Feng B, Zhao X, Jiang X and Tao J: Low-voltage-activated T-type $\mathrm{Ca}^{2+}$ channel inhibitors as new tools in the treatment of glioblastoma: The role of endostatin. Pflugers Arch 466: 811-818, 2014.

16. Wang XT, Nagaba Y, Cross HS, Wrba F, Zhang L and Guggino SE: The mRNA of L-type calcium channel elevated in colon cancer: Protein distribution in normal and cancerous colon. Am J Pathol 157: 1549-1562, 2000.

17. Vanden Abeele F, Lemonnier L, Thébault S, Lepage G, Parys JB, Shuba Y, Skryma R and Prevarskaya N: Two types of storeoperated $\mathrm{Ca}^{2+}$ channels with different activation modes and molecular origin in LNCaP human prostate cancer epithelial cells. J Biol Chem 279: 30326-30337, 2004.

18. Catterall WA and Zheng N: Deciphering voltage-gated $\mathrm{Na}(+)$ and $\mathrm{Ca}(2+)$ channels by studying prokaryotic ancestors. Trends Biochem Sci 40: 526-534, 2015.
19. González C, Baez-Nieto D, Valencia I, Oyarzún I, Rojas P, Naranjo D and Latorre R: $\mathrm{K}(+)$ channels: Function-structural overview. Compr Physiol 2: 2087-2149, 2012.

20. Firth AL, Remillard CV, Platoshyn O, Fantozzi I, Ko EA and Yuan JX: Functional ion channels in human pulmonary artery smooth muscle cells: Voltage-dependent cation channels. Pulm Circ 1: 48-71, 2011

21. Voglis $\mathrm{G}$ and Tavernarakis $\mathrm{N}$ : The role of synaptic ion channels in synaptic plasticity. EMBO Rep 7: 1104-1110, 2006.

22. Hua SZ, Gottlieb PA, Heo J and Sachs F: A mechanosensitive ion channel regulating cell volume. Am J Physiol Cell Physiol 298: C1424-C1430, 2010

23. Sardini A, Amey JS, Weylandt KH, Nobles M, Valverde MA and Higgins CF: Cell volume regulation and swelling-activated chloride channels. Biochim Biophys Acta 1618: 153-162, 2003.

24. Subramanyam $P$ and Colecraft HM: Ion channel engineering: Perspectives and strategies. J Mol Biol 427: 190-204, 2015.

25. Grosse W, Essen LO and Koert U: Strategies and perspectives in ion-channel engineering. ChemBioChem 12: 830-839, 2011.

26. Yang B, Cao L, Liu J, Xu Y, Milne G, Chan W, Heys SD, McCaig $\mathrm{CD}$ and $\mathrm{Pu} \mathrm{J}$ : Low expression of chloride channel accessory 1 predicts a poor prognosis in colorectal cancer. Cancer 121: 1570-1580, 2015.

27. Ievglevskyi O, Isaev D, Netsyk O, Romanov A, Fedoriuk M, Maximyuk O, Isaeva E, Akaike $\mathrm{N}$ and Krishtal O: Acid-sensing ion channels regulate spontaneous inhibitory activity in the hippocampus: Possible implications for epilepsy. Philos Trans R Soc Lond B Biol Sci 371: 1-9, 2016.

28. Feske S, Wulff $\mathrm{H}$ and Skolnik EY: Ion channels in innate and adaptive immunity. Annu Rev Immunol 33: 291-353, 2015.

29. Bulman DE: Phenotype variation and newcomers in ion channel disorders. Hum Mol Genet 6: 1679-1685, 1997.

30. Xu J, Yang Y, Xie R, Liu J, Nie X, An J, Wen G, Liu X, Jin H and Tuo B: The NCX1/TRPC6 complex mediates TGF $\beta$-driven migration and invasion of human hepatocellular carcinoma cells. Cancer Res 78: 2564-2576, 2018

31. Moharil RB, Dive A, Khandekar S and Bodhade A: Cancer stem cells: An insight. J Oral Maxillofac Pathol 21: 463, 2017.

32. Reya T, Morrison SJ, Clarke MF and Weissman IL: Stem cells, cancer, and cancer stem cells. Nature 414: 105-111, 2001.

33. Peters T: Calcium in physiological and pathological cell function. Eur Neurol 25 (Suppl 1): 27-44, 1986.

34. Monteith GR, Davis FM and Roberts-Thomson SJ: Calcium channels and pumps in cancer: Changes and consequences. J Biol Chem 287: 31666-31673, 2012.

35. D'Ascenzo M, Piacentini R, Casalbore P, Budoni M, Pallini R, Azzena GB and Grassi C: Role of L-type $\mathrm{Ca}^{2+}$ channels in neural stem/progenitor cell differentiation. Eur J Neurosci 23: 935-944, 2006.

36. Stewart TA, Yapa KT and Monteith GR: Altered calcium signaling in cancer cells. Biochim Biophys Acta 1848B: 2502-2511, 2015.

37. Xie J, Pan H, Yao J, Zhou Y and Han W: SOCE and cancer: Recent progress and new perspectives. Int J Cancer 138: 2067-2077, 2016

38. Prakriya M and Lewis RS: Store-operated calcium channels. Physiol Rev 95: 1383-1436, 2015.

39. Lee SH, Rigas NK, Lee CR, Bang A, Srikanth S, Gwack Y, Kang MK, Kim RH, Park NH and Shin KH: Orail promotes tumor progression by enhancing cancer stemness via NFAT signaling in oral/oropharyngeal squamous cell carcinoma. Oncotarget 7: 43239-43255, 2016.

40. Zhao W, Wang L, Han H, Jin K, Lin N, Guo T, Chen Y, Cheng H, Lu F, Fang W, et al: 1B50-1, a mAb raised against recurrent tumor cells, targets liver tumor-initiating cells by binding to the calcium channel $\alpha 2 \delta 1$ subunit. Cancer Cell 23 . $541-556,2013$

41. Liu M, Inoue K, Leng T, Guo S and Xiong ZG: TRPM7 channels regulate glioma stem cell through STAT3 and Notch signaling pathways. Cell Signal 26: 2773-2781, 2014.

42. Morelli MB, Nabissi M, Amantini C, Farfariello V, RicciVitiani L, di Martino S, Pallini R, Larocca LM, Caprodossi S, Santoni M, et al: The transient receptor potential vanilloid-2 cation channel impairs glioblastoma stem-like cell proliferation and promotes differentiation. Int J Cancer 131: E1067-E1077, 2012.

43. Curci A, Mele A, Camerino GM, Dinardo MM and Tricarico D: The large conductance $\mathrm{Ca}(2+)$-activated $\mathrm{K}(+)(\mathrm{BKCa})$ channel regulates cell proliferation in SH-SY5Y neuroblastoma cells by activating the staurosporine-sensitive protein kinases. Front Physiol 5: 476, 2014 
44. Rosa P, Sforna L, Carlomagno S, Mangino G, Miscusi M, Pessia M, Franciolini F, Calogero A and Catacuzzeno L: Overexpression of large-conductance calcium-activated potassium channels in human glioblastoma stem-like cells and their role in cell migration. J Cell Physiol 232: 2478-2488, 2017.

45. Zhang YY, Yue J, Che H, Sun HY, Tse HF and Li GR: BKCa and hEag1 channels regulate cell proliferation and differentiation in human bone marrow-derived mesenchymal stem cells. J Cell Physiol 229: 202-212, 2014

46. Nio K, Yamashita T and Kaneko S: The evolving concept of liver cancer stem cells. Mol Cancer 16: 4, 2017.

47. Heubach JF, Graf EM, Leutheuser J, Bock M, Balana B Zahanich I, Christ T, Boxberger S, Wettwer E and Ravens U: Electrophysiological properties of human mesenchymal stem cells. J Physiol 554: 659-672, 2004.

48. Li G-R, Sun H, Deng X and Lau CP: Characterization of ionic currents in human mesenchymal stem cells from bone marrow. Stem Cells 23: 371-382, 2005.

49. Wang S-P, Wang J-A, Luo R-H, Cui W-Y and Wang H: Potassium channel currents in rat mesenchymal stem cells and their possible roles in cell proliferation. Clin Exp Pharmacol Physiol 35: 1077-1084, 2008

50. Pardo LA and Stühmer W: The roles of $\mathrm{K}(+)$ channels in cancer. Nat Rev Cancer 14: 39-48, 2014

51. Wang ZH, Shen B, Yao HL, Jia YC, Ren J, Feng YJ and Wang YZ: Blockage of intermediate-conductance- $\mathrm{Ca}(2+)$-activated $\mathrm{K}(+)$ channels inhibits progression of human endometrial cancer. Oncogene 26: 5107-5114, 2007.

52. Rao VR, Perez-Neut M, Kaja S and Gentile S: Voltage-gated ion channels in cancer cell proliferation. Cancers (Basel) 7: 849-875, 2015.

53. Šatková J and Bébarová M: Functional impact of hERG: From physiological role to target of anticancer therapy. Vnitr Lek 63: 114-123, 2017 (In Czech).

54. Li H, Liu L, Guo L, Zhang J, Du W, Li X, Liu W, Chen X and Huang S: HERG $\mathrm{K}^{+}$channel expression in $\mathrm{CD}^{+} 4^{+} / \mathrm{CD} 38^{-}$ CD123(high) cells and primary leukemia cells and analysis of its regulation in leukemia cells. Int J Hematol 87: 387-392, 2008.

55. Jehle J, Schweizer PA, Katus HA and Thomas D: Novel roles for hERG K(+) channels in cell proliferation and apoptosis. Cell Death Dis 2: e193, 2011.

56. Kubota D, Orita H, Yoshida A, Gotoh M, Kanda T, Tsuda H, Hasegawa T, Katai H, Shimada Y, Kaneko K, et al: Pfetin as a prognostic biomarker for gastrointestinal stromal tumor: Validation study in multiple clinical facilities. Jpn J Clin Oncol 41: 1194-1202, 2011.

57. Li L, Duan T, Wang X, Zhang RH, Zhang M, Wang S, Wang F, Wu Y, Huang $\mathrm{H}$ and Kang T: KCTD12 Regulates colorectal cancer cell stemness through the ERK pathway. Sci Rep 6: 20460, 2016

58. Jentsch TJ, Stein V, Weinreich F and Zdebik AA: Molecular structure and physiological function of chloride channels. Physio Rev 82: 503-568, 2002

59. Nako Y, Shiozaki A, Ichikawa D, Komatsu S, Konishi H, Iitaka D, Ishii H, Ikoma H, Kubota T, Fujiwara H, et al: Enhancement of the cytocidal effects of hypotonic solution using a chloride channel blocker in pancreatic cancer cells. Pancreatology 12 440-448, 2012

60. Soroceanu L, Manning TJ Jr and Sontheimer H: Modulation of glioma cell migration and invasion using $\mathrm{Cl}(-)$ and $\mathrm{K}(+)$ ion channel blockers. J Neurosci 19: 5942-5954, 1999.

61. Setti M, Savalli N, Osti D, Richichi C, Angelini M, Brescia P, Fornasari L, Carro MS, Mazzanti M and Pelicci G: Functional role of CLIC1 ion channel in glioblastoma-derived stem/ progenitor cells. J Natl Cancer Inst 105: 1644-1655, 2013

62. Deng YJ, Tang N, Liu C, Zhang JY, An SL, Peng YL, Ma LL, Li GQ, Jiang Q, Hu CT, et al: CLIC4, ERp29, and Smac/ DIABLO derived from metastatic cancer stem-like cells stratify prognostic risks of colorectal cancer. Clin Cancer Res 20: 3809-3817, 2014.

63. Higgins CF: Volume-activated chloride currents associated with the multidrug resistance P-glycoprotein. J Physiol 482 (Suppl) 31S-36S, 1995

64. Zhao L, Zhao Y, Schwarz B, Mysliwietz J, Hartig R, Camaj P, Bao Q, Jauch KW, Guba M, Ellwart JW, et al: Verapamil inhibits tumor progression of chemotherapy-resistant pancreatic cancer side population cells. Int J Oncol 49: 99-110, 2016
65. Comes N, Bielanska J, Vallejo-Gracia A, Serrano-Albarrás A, Marruecos L, Gómez D, Soler C, Condom E, Ramón Y Cajal S, Hernández-Losa J, et al: The voltage-dependent $\mathrm{K}(+)$ channels Kv1.3 and Kv1.5 in human cancer. Front Physiol 4: 283, 2013.

66. Fraser SP, Grimes JA and Djamgoz MB: Effects of voltage-gated ion channel modulators on rat prostatic cancer cell proliferation: Comparison of strongly and weakly metastatic cell lines. Prostate 44: 61-76, 2000.

67. D'Alessandro G, Grimaldi A, Chece G, Porzia A, Esposito V, Santoro A,Salvati M, Mainiero F, Ragozzino D, Di Angelantonio S, et al: KCa3.1 channel inhibition sensitizes malignant gliomas to temozolomide treatment. Oncotarget 7: 30781-30796, 2016.

68. Kang MK and Kang SK: Pharmacologic blockade of chloride channel synergistically enhances apoptosis of chemotherapeutic drug-resistant cancer stem cells. Biochem Biophys Res Commun 373: 539-544, 2008

69. Gritti M, Würth R, Angelini M, Barbieri F, Peretti M, Pizzi E, Pattarozzi A, Carra E, Sirito R, Daga A, et al: Metformin repositioning as antitumoral agent: Selective antiproliferative effects in human glioblastoma stem cells, via inhibition of CLIC1-mediated ion current. Oncotarget 5: 11252-11268, 2014.

70. Chiu LY, Ko JL, Lee YJ, Yang TY, Tee YT and Sheu GT: L-type calcium channel blockers reverse docetaxel and vincristineinduced multidrug resistance independent of ABCB1 expression in human lung cancer cell lines. Toxicol Lett 192: 408-418, 2010

71. Firuzi O, Javidnia K, Mansourabadi E, Saso L, Mehdipour AR and Miri R: Reversal of multidrug resistance in cancer cells by novel asymmetrical 1,4-dihydropyridines. Arch Pharm Res 36: 1392-1402, 2013

72. Lapidot T, Sirard C, Vormoor J, Murdoch B, Hoang T, CaceresCortes J, Minden M, Paterson B, Caligiuri MA and Dick JE: A cell initiating human acute myeloid leukaemia after transplantation into SCID mice. Nature 367: 645-648, 1994.

73. Bonnet D and Dick JE: Human acute myeloid leukemia is organized as a hierarchy that originates from a primitive hematopoietic cell. Nat Med 3: 730-737, 1997.

74. Hu G, Li F, Ouyang K, Xie F, Tang X, Wang K, Han S, Jiang Z, Zhu M, Wen D, et al: Intrinsic gemcitabine resistance in a novel pancreatic cancer cell line is associated with cancer stem cell-like phenotype. Int J Oncol 40: 798-806, 2012.

75. de la Mare JA, Sterrenberg JN, Sukhthankar MG, Chiwakata MT, Beukes DR, Blatch GL and Edkins AL: Assessment of potential anti-cancer stem cell activity of marine algal compounds using an in vitro mammosphere assay. Cancer Cell Int 13: 39, 2013.

76. Kise K, Kinugasa-Katayama Y and Takakura N: Tumor microenvironment for cancer stem cells. Adv Drug Deliv Rev 99B 197-205, 2016.

77. Broz ML, Binnewies M, Boldajipour B, Nelson AE, Pollack JL, Erle DJ, Barczak A, Rosenblum MD, Daud A, Barber DL, et al: Dissecting the tumor myeloid compartment reveals rare activating antigen-presenting cells critical for $\mathrm{T}$ cell immunity. Cancer Cell 26: 638-652, 2014

78. Ishiwata T: Cancer stem cells and epithelial-mesenchymal transition: Novel therapeutic targets for cancer. Pathol Int 66: 601-608, 2016

79. Plaks V, Kong N and Werb Z: The cancer stem cell niche: How essential is the niche in regulating stemness of tumor cells? Cell Stem Cell 16: 225-238, 2015.

80. Wang L, Fan J, Hitron JA, Son YO, Wise JT, Roy RV, Kim D, Dai J, Pratheeshkumar P, Zhang Z, et al: Cancer stem-like cells accumulated in nickel-induced malignant transformation. Toxicol Sci 151: 376-387, 2016

81. Oskarsson T, Batlle E and Massagué J: Metastatic stem cells: Sources, niches, and vital pathways. Cell Stem Cell 14: 306-321, 2014.

82. Tian Y, Bresenitz P, Reska A, El Moussaoui L, Beier CP and Gründer S: Glioblastoma cancer stem cell lines express functional acid sensing ion channels ASICla and ASIC3. Sci Rep 7: $13674,2017$.

83. Shiozaki A, Kudou M, Ichikawa D, Fujiwara H, Shimizu H, Ishimoto T, Arita T, Kosuga T, Konishi H, Komatsu S, et al: Esophageal cancer stem cells are suppressed by tranilast, a TRPV2 channel inhibitor. J Gastroenterol 53: 197-207, 2018.

84. Bao B, Azmi AS, Li Y, Ahmad A, Ali S, Banerjee S, Kong D and Sarkar FH: Targeting CSCs in tumor microenvironment: The potential role of ROS-associated miRNAs in tumor aggressiveness. Curr Stem Cell Res Ther 9: 22-35, 2014. 